\title{
HIPOKRATOVA PRISEGA IN NJEN POMEN ZA MEDICINSKO DEONTOLOGIJO
}

\author{
VLASTA MOČNIK DRNOVŠEK
}

\begin{abstract}
Izvleček
Hipokratova prisega je najbolj slavna etična izjava hipokratskih spisov. Zdravnika zavezuje $\mathrm{k}$ najvišjim tehničnim in etičnim standardom, ki so se ohranili do danes. Raziskovanje besedila prisege in hipokratske misli odpira različne plasti in razsežnosti razumevanja etičnih norm, zdravja, bolezni, narave in življenja. Kompleksnost hipokratske morale terja pri razlaganju sodelovanje različnih ved in odpira vedno nove možnosti za raziskovanje, vrednotenje in prispevek k boljšemu razumevanju celote hipokratske misli, ki neločljivo poveže strokovna in moralna vprašanja medicinske prakse in teorije $\mathrm{v}$ interakciji $\mathrm{z}$ naravnim in družbenim okoljem človeka.
\end{abstract}

\begin{abstract}
The Hippocratic Oath is the most famous ethical statement of the Hippocratic Corpus. It binds the physician to the highest technical and ethical standards of medicine, which have laid the foundation of modern medical ethics. The study of the text of the Oath and of the Hippocratic thought reveals various layers and dimensions of understanding and interpreting ethical norms and such concepts as health and disease, nature and life. The complexity of the Hippocratic ethics demands the cooperation of various sciences for its interpretation, ever providing new possibilities of critical assessment and of contributing to a better understanding of the Hippocratic thought as a whole, which, in interaction with the natural and social environment, inseparably links the technical and moral questions of medical practice and theory.
\end{abstract}

\section{UVOD}

»Hipokrat s Kosa, Asklepijad,« tako so za njegovega življenja imenovali znamenitega zdravnika, da so ga ločevali od drugih Hipokratov, ker je bilo v tistem času to ime pogosto. Ime opredeljuje Hipokratovo domovino in njegovo družinsko poreklo. Kot 
je možno domnevati na podlagi antičnih virov, ${ }^{1}$ se je rodil okrog leta 460/59 na otoku Kosu v družini Asklepiadov, bil je vodilni zdravnik šole na Kosu in je kot zdravnik potoval po Grčiji. Umrl naj bi v Larisi okrog leta 370 pr. n. št. V Platonovem dialogu Fajdros Sokrat sprašuje, ali je mogoče »doumeti naravo duše, ne da bi doumeli naravo celote?» in Fajdros odgovarja, »če je treba verjeti Asklepijevemu potomcu Hipokratu, brez tega postopka to ni mogoče niti glede telesa«. ${ }^{2}$ Ta dialog kaže na dejstvo, da je imela Hipokratova misel v antični Grčiji pomemben vpliv. Medicinski nazori o telesu in človeku so pogosto služili kot opora filozofskemu razmišljanju. ${ }^{3}$ Nekaj deset let kasneje je v svojem delu Hipokrata omenjal tudi Aristotel, ki je bil rojen v zdravniški družini, in hkrati priporočal filozofom, naj se seznanijo z medicino. ${ }^{4}$

Hipokrata štejemo za utemeljitelja znanstvene medicine in medicinske etike, sodi pa tudi med začetnike filozofske antropologije in ekologije. V tej zvezi je potrebno omeniti, da je $v$ tistem času izobraževanje zdravnika obsegalo ne le znanja o človeku, temveč tudi retoriko, matematiko in verjetno filozofijo kot razumevanje sveta in narave. Antični viri (Strabon, Plinij Starejši) ${ }^{5}$ omenjajo, da je Hipokrat pridobil medicinska znanja s pomočjo zapisov na votivnih ploščah v svetišču Asklepija na Kosu, vendar raziskovalci takšnih plošč niso našli. Večina avtorjev meni, da racionalna medicina Asklepijevih potomcev ni izšla iz Asklepijevega svetišča in da je to tradicijo verjetno razširila duhovščina, da bi slavo velikega zdravnika s Kosa obrnila tudi sebi v korist. ${ }^{6}$ Zato kritično preučevanje različnih antičnih virov o Hipokratu, njegovem življenju in delu ostaja izziv za klasično filologijo ter za zgodovino znanosti in filozofije, kajti meja med legendo in zgodovino še vedno ni jasno postavljena.

Hipokratska medicina se umešča $\mathrm{v}$ zgodovino predsokratske filozofije in znanosti. Podobo človeka je zasnovala na preučevanju narave in zavrnila razumevanje bolezni kot poseganje bogov v procese nastanka in zdravljenja. Hipokrat v spisu $O$

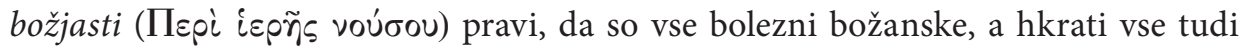
človeške. ${ }^{7}$ Tako postane "nasprotje med božjim in človeškim nevtralizirano v medicinski perspektivi. ${ }^{8}$

Hipokratska medicina razume človeka kot celoto in $\mathrm{v}$ dinamični interakciji $\mathrm{z}$ naravnim in kulturnim okoljem, $\mathrm{v}$ katerem živi. S tem postavlja temelj vedam o člo-

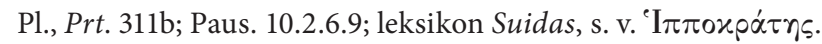

Pl., Phdr. 270c. Prevod Gorazd Kocijančič.

3 Nekaj primerov: Platonova teorija človeka v zaključnem delu dialoga Timaj povzema dognanja tedanje medicine; stoiška etika apatije se pogosto opira na tedanje medicinske nazore. Najbolj očiten primer vpliva medicine na filozofsko etiko je Galenov spis $O$ čustvih in zmotah (Пвpi

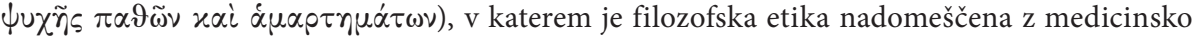
dietetiko.

4 Jouanna, Hippocrate, 17-21.

5 Plin., H.N. 29.4.3, Str. 14.2.19.

6 Jouanna, Hippocrate, 35.

7 Hp., Morb. Sacr. 21.

8 Jouanna, Hippocrate, 299.
} 
veku in hkrati utemeljuje ekologijo, ker preučuje različne okoljske vplive na zdrav-

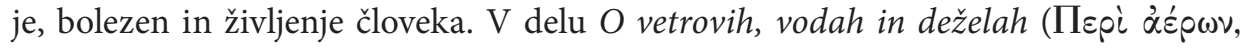

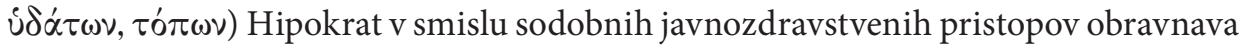
različne vplive na zdravje ljudi in povezuje medicino $\mathrm{z}$ etnografijo in antropologijo. Hipokratski zdravnik je tako razširil etiološko metodo, ki jo je razvil na osnovi medicinske izkušnje, na področje etnografije in ekologije, ko je preučeval klimatske vplive na telesne in vedenjske značilnosti človeka in različnih skupnosti. Poleg klimatskih vplivov in vplivov naravnega okolja je hipokratski zdravnik upošteval tudi vplive kulturnega okolja na zdravje in življenje ljudi. Ta človeški faktor, »ki ga Grki imenujejo vóuos in ki sočasno pokriva običaje in zakone, « je danes prepoznan kot odločujoč za zdravje ljudi.

Hipokratski spisi zato ne utemeljujejo le sodobne, na znanosti utemeljene medi-

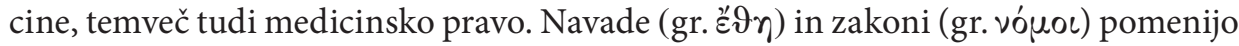
za skupnost to, kar pomeni pravi način življenja (gr. Si $\alpha \iota \tau \alpha$ ) za zdravje posameznika. Kakor življenjski slog posameznika odločilno vpliva na njegovo zdravje, tako tudi običaji in zakoni vplivajo na zdravje in moralo skupnosti. ${ }^{10}$

Pomemben vidik hipokratske medicine predstavlja medicinska deontologija, ki opredeljuje zdravnikov odnos do bolnika, njegov racionalen odnos do bolezni in hkrati pomeni kritično refleksijo zdravnika o njegovi dejavnosti. Ti vidiki medicinskega delovanja in medicinske ter filozofske refleksije so strnjeni v besedilu Hipokratove prisege, ki ga bomo podrobneje predstavili.

\section{OPKO}

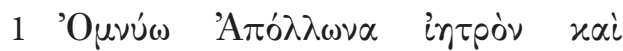

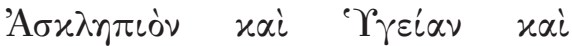

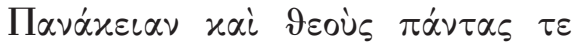

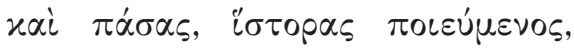

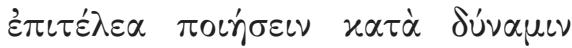

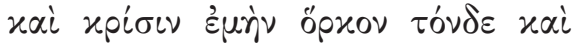

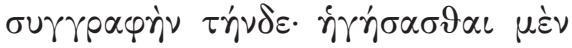

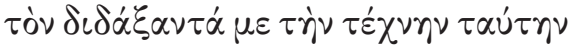

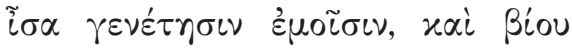

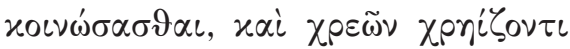

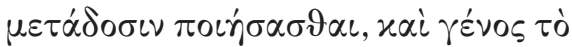

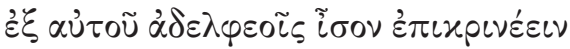

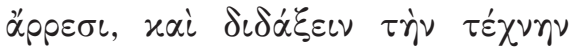

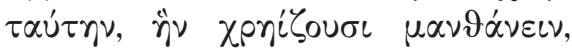

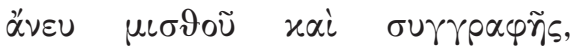

9 Jouanna, Hippocrate, 313

10 Jouanna, Hippocrate, 314.

\section{PRISEGA}

1 Prisegam na Apolona zdravnika in Asklepija, na Higiejo in Panakejo, na vse bogove in vse boginje, ki jih jemljem za priče, da bom po svoji moči in sodbi izpolnjeval tole prisego in tole pismeno pogodbo: da bom tistega, ki me je izučil te vede, cenil enako kakor svoje starše; da bom z njim delil življenjska sredstva in če bo v pomanjkanju, mu bom predal del svojega imetja; da bom njegove potomce imel za enake svojim lastnim bratom in jih bom poučeval v tej vedi, če se je želijo naučiti, brez plačila in brez pisne pogodbe; nauk, ustno razlago 


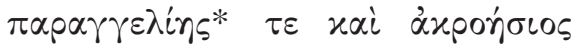

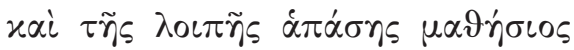

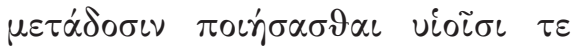

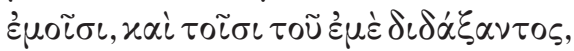

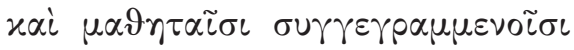

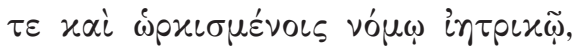
$\dot{\alpha} \lambda \lambda \omega \dot{\delta} \delta \dot{\varepsilon}$ oủdeví.

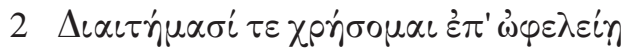

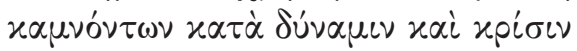

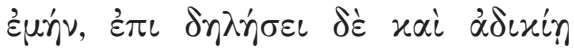
$\varepsilon i p \xi \varepsilon \iota v$.

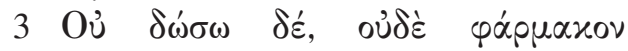

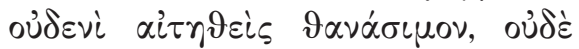

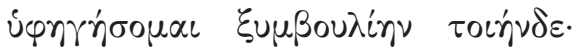

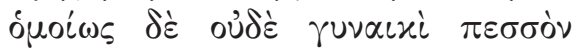

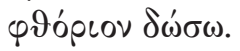

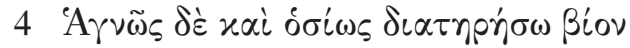

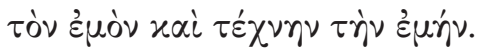

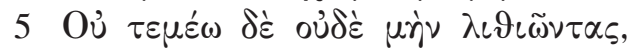

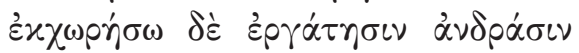
$\pi p \dot{\xi} \xi \cos \tau \tilde{n} \sigma \delta \varepsilon$.

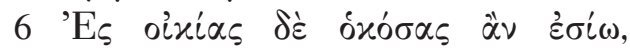

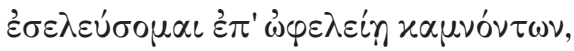

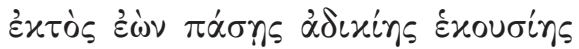

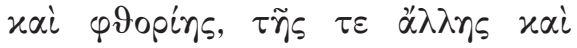

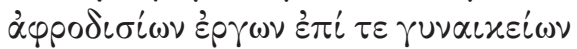

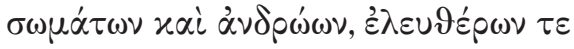

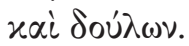

7 'A $\delta$ ' $\alpha \nu$ हे

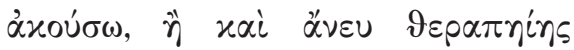

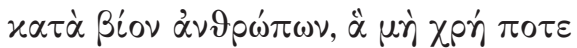

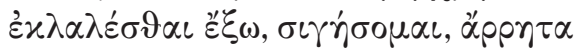

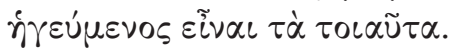

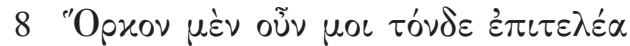

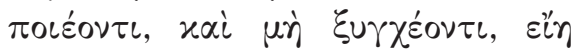

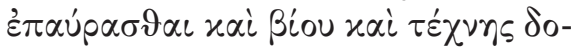

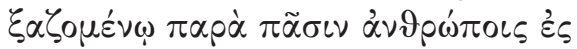

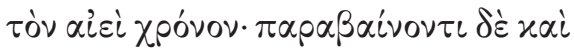

Gr. $\pi \alpha p \alpha \gamma \gamma \varepsilon \lambda$ in 'nauk'; prim. Aristotel, EN 1104a7. Aristotel je moral prisego poznati. in vse ostalo znanje bom posredoval tako svojim sinovom kakor sinovom tistega, ki me je izučil, in učencem, ki jih veže pogodba in prisega ${ }^{\star} \mathrm{v}$ skladu z medicinskim zakonom, sicer pa nikomur drugemu.

2 Medicinske ukrepe bom uporabljal $\mathrm{v}$ korist bolnikov po svoji moči in svoji sodbi; če pa je to njim v pogubo in krivico, prisegam, da bom to preprečeval.

3 Prav tako nikomur ne bom izročil smrtnega zdravila, tudi če me zanj zaprosi, niti ne bom spodbudil takšnega nasveta; prav tako nobeni ženski ne bom dal abortivnega pesarja.

4 Svoje življenje in svojo vedo bom ohranjal čisto in sveto.

5 Ne bom operiral niti tistih bolnikov, ki imajo kamne, temveč bom to prepustil specialistom za te posege.

6 V vse hiše, v katere bom prišel, bom vstopil v korist bolnikov in se držal stran od vsake hotene krivice in vsakega koruptivnega dejanja, še posebej pa od ljubezenskih dejanj na telesih žensk in moških, svobodnih ali sužnjev.

7 Vse, kar bom v teku zdravljenja ali celo izven zdravljenja videl ali slišal o življenju ljudi takega, da se tega nikoli ne sme govoriti zunaj, bom zamolčal, ker menim, da morajo takšne stvari ostati tajne.

8 Če bom torej to prisego izvrševal in je ne bom kršil, naj mi bo dano uži-

Lami, Ippocrate, 257, ob tem pripominja: „Očitno drugačna prisega kakor je ta, ki je bila dana na začetku medicinskega izobraževanja. Po pričujoči prisegi naj bi se zaprisegalo ob koncu izobraževanja in na začetku samostojne poklicne prakse.« 


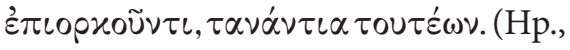
Jusj.; Corpus medicorum Graecorum $1.1,4.2-5.10)$ vati sadove svojega življenja in svoje vede, v spoštovanju od vseh ljudi za ves čas; če pa jo bom prelomil in krivo prisegel, naj me doleti nasprotno od tega.

V slovenščini obstaja več prevodov Hipokratove prisege. ${ }^{11}$ Najbolj znan in najpogosteje uporabljan je prevod Antona Sovreta. Zaradi večplastnega pomena besedila smo prevode ponovno primerjali $\mathrm{z}$ originalnim besedilom in izdelali nov prevod, ki je morda bolj jasen, natančen in bliže sodobnemu medicinskemu jeziku ter izrazoslovju govora o človekovih pravicah. Kot primere razlik med prevodi lahko navedemo naslednje izraze:

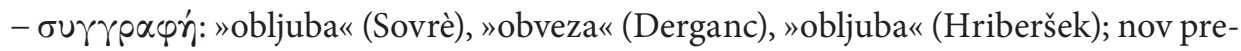
vod: pisna pogodba;

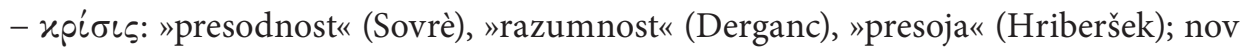
prevod: sodba;

- $\pi \alpha \rho \alpha \gamma \gamma \varepsilon \lambda i \eta$ : "strokovna navodila" (Sovrè), "predpisi« (Derganc), "predpisi« (Hriberšek); nov prevod: nauk;

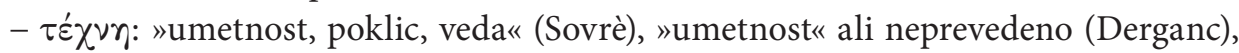
"umetnost, stroka" (Hriberšek); nov prevod: veda;

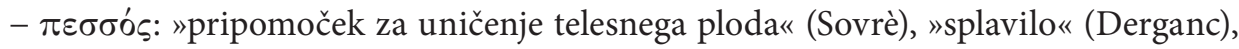
"splavilo« (Hriberšek); nov prevod: abortivni pesar;

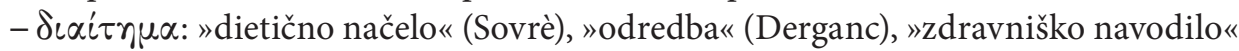
(Hriberšek); nov prevod: medicinski ukrep.

Prevod je nastal na podlagi Heibergove izdaje Hipokratove prisege. ${ }^{12}$ Iz te izdaje je prevzeta tudi členitev besedila.

Prevod je vedno tudi odraz določenega razumevanja besedila in razlaganja glede na celoto hipokratskih spisov in zgodovinski kontekst. Razlago Hipokratove prisege umeščamo $\mathrm{v}$ sodoben koncept zdravja in človekovih pravic znotraj sistematičnih prizadevanj za zagotavljanje varnosti in kakovosti zdravstvenih storitev, ki terjajo stalno presojo medicinskih praks v odnosu do družbenega in naravnega okolja ter spodbujanje sodelovanja bolnikov in državljanov v procesih odločanja o zdravju.

11 Prevodi: Sovrè, »Hipokratova prisega,«21; Derganc, »Hipokratova prisega,« 29; Hriberšek, »Hipokratova prisega, «9. Pričujoči prevod sta pripravila avtorica in V. K.

12 Heiberg, Corpus medicorum Graecorum 1.1, 4-5, in Lami, Ippocrate, 256-258. 


\section{STRUKTURA IN VSEBINA HIPOKRATOVE PRISEGE}

Hipokratovo prisego lahko opišemo kot »svečano zaprisego«, kjer ima vsaka beseda svoje mesto, namen in težo, in to ne le v okviru medicine in medicinske etike, temveč tudi kozmologije in teorije človeka. Prisega se sklicuje na grške boginje in bogove, zato prisežniku nalaga odgovornost in zavezo, ki ima poleg človeških tudi metafizične razsežnosti. Prisega s tem postavlja človekovo nepopolno znanje in delovanje v odnos do božje popolnosti.

Zdravnik se zaveda svojih omejitev, nepopolnega znanja, zavajajočih preskusov, odgovornih odločitev, negotovih izidov in morebitnih nasprotnih učinkov zdravil, dietetičnih ukrepov in drugih terapij, zato deluje previdno in postopno ter se izogiba skrajnosti. Zdravnik se mora tehtno odločati v vsakem primeru posebej in natančno preučiti vse okoliščine zdravljenja. Svoje naloge ne opravlja sam, temveč si mora pri tem zagotoviti sodelovanje bolnika in njegove okolice. ${ }^{13}$ Prisego zdravnik izpolnjuje le po svojih najboljših močeh in po svoji najboljši presoji s sredstvi in znanji, ki jih ima na voljo kot človek. Ob zavedanju svojih omejitev in hkrati svojega potenciala za dobro se zdravnik zaveže, da bo svoje življenje ohranjal neomadeževano in sveto, ker bo le tako lahko sledil svojim človeškim in strokovnim idealom.

Hipokratovo prisego kot zavezo svetosti življenju lahko razumemo tudi kot zavezo k odličnosti življenja in medicinskega delovanja zdravnika, ki je posvečen $\mathrm{v}$ sveta vprašanja življenja in smrti. To zdravnika postavlja $\mathrm{v}$ odnosu do ostalih ljudi in do božjega $v$ posebno pozicijo. Osebna in strokovna rast ter napredek stroke terja ne le celovito vrednotenje praks v perspektivi končnih ciljev, temveč tudi filozofsko refleksijo in družbeno angažiranje. Takšne naloge zmore le majhno število ljudi, zato je že Hipokrat ugotavljal, da je zdravnikov veliko po nazivu, vendar malo v resnici. Da bi zdravnik lahko učinkovito deloval v korist bolnikov in jih varoval pred škodo in krivico, mora imeti specifične človeške in strokovne kvalitete. Zato je za zdravnika ključnega pomena kakovost izobraževanja in medosebnih odnosov. Da bi dosegel visoko postavljene strokovne in moralne norme, ki jih terja prisega, mora zdravnik v svoji stroki in življenju izpolnjevati zahteve zdravniškega zakona ter ohranjati svoje osebno dostojanstvo in strokovno integriteto. Če zdravnik prisego prelomi, izgubi svoj človeški in strokovni ugled. Še v novejšem času so nekatera zdravniška združenja določila prisege jemala dobesedno in ob hudih kršitvah zdravnike izključila iz svojih vrst. $^{14}$

Prvi sklop prisege opredeljuje naloge zdravnika do sinov ali učencev njegovih učiteljev, govori pa tudi o povezanosti, spoštovanju in solidarnosti z učiteljem in drugimi zdravniki, ki so prisegli po zdravniškem zakonu. Zgolj med zapriseženci lahko obstaja vzdušje bratstva, prost pretok znanja in izkušenj. Vsi drugi so iz bratovščine

13 Hp., Aph. 1.1.

14 Nutton, »Hippocratic Morality and Modern Medicine, 50. 
izločeni. Prisega je tisti zakon in hkrati tista garancija, ki odpira vrata v medicinsko stroko, ker človeka zaveže v celoti njegovega bivanja. Od zdravnika zahteva strokovno in moralno odličnost, ki jo zdravnik potrebuje v prizadevanjih za dobro drugega človeka. Šele stalno stremljenje k preseganju človeških omejitev in slabosti lahko na neki način posveti zdravnika za delo s trpečimi ljudmi. Ker zdravnik s svojimi dejanji posega $\mathrm{v}$ samo bit in svetost življenja, lahko prisego razumemo tudi kot neko vrsto iniciacije v skrivnosti narave in človeka, ki je omogočena le nekaterim ljudem. Zahteve prisege po ohranjanju življenja vidimo v »metafizični« perspektivi v smislu izvorne svetosti življenja, ki jo zdravnik v svoji filozofski in strokovno medicinski naravnanosti potrjuje in izkazuje v svojih dejanjih. Številni avtorji sicer opozarjajo, da se je $\mathrm{v}$ antiki medicinska praksa, ki ni prepovedovala splava in pomoči pri samomoru, močno razlikovala od norm - tehničnih in moralnih - medicinskega delovanja, ki jih postavlja Hipokratova prisega.$^{15}$ Vendar ta dejstva zgolj potrjujejo nujnost univerzalnih etičnih norm, ki se ohranjajo od Hipokrata dalje. V tem smislu lahko iščemo analogije $\mathrm{z}$ razumevanjem in udejanjanjem sodobnega koncepta človekovih pravic $\mathrm{v}$ času številnih kršitev človeškega dostojanstva in temeljnih svoboščin.

Drugi sklop zadeva odnos zdravnika do stroke in bolnikov in $s$ tem neločljivo poveže medicinska strokovna ali tehnična vprašanja ter moralna vprašanja. Izpostavlja pomen kakovosti delovanja, zaupnosti in diskretnosti, ker si je le tako zdravnik lahko pridobil zaupanje bolnika in njegovih svojcev, ki je bilo nujno za njihovo sodelovanje. Razmislek o etičnih normah medicinskega delovanja je bil sestavni del postopkov kritične analize, vrednotenja tveganj in izidov zdravljenja ter preučevanja pogojev, sredstev in okoliščin, ki omogočajo dobre rezultate. Hipokratski zdravnik je vedel, da je zaupanje in sodelovanje bolnika predpogoj za uspešen proces zdravljenja, zato je na prvo mesto postavil načelo bolnikove koristi in zagotavljanje varne storitve. »Etične izjave, ki jih vsebujejo spisi, kot je Hipokratova prisega, so se razvile iz vzorca zdravilskih praks, ki so od zdravnika-zdravilca zahtevale natančno preučevanje bolnikovega telesa, ... pacienti pa so potrebovali zagotovilo, da bodo oni in njihovi družinski člani obravnavani dostojanstveno ....116 Pri izbiri določenih metod zdravljenja zdravnik vedno razsoja $\mathrm{v}$ bolnikovo korist, kolikor je to le v njegovi moči. Po drugi strani pa bolnike vedno varuje pred škodo in krivicami, kar presega neposredni odnos zdravljenja in posega na širše področje zdravnikovega javnega delovanja in angažiranja. V skladu s sodobnim konceptom javnega zdravja si zdravnik prizadeva za zdravje in dobrobit svojih pacientov in tudi za varovanje zdravja populacije, ker je to hkrati v korist vsakega posameznega pacienta. $Z$ medicinskega vidika je pomembno, da prisega omenja varnost in kakovost zdravnikovega dela, zato zdravnik operacijo kamnov prepušča kirurgu, ki je v tem

15 Kazenski zakonik Republike Slovenije prepoveduje napeljevanje k samomoru in pomoč pri samomoru (131. člen) ter opredeljuje odstopanja od zdravstvenih pogojev in načinov umetne prekinitve nosečnosti (132. člen).

16 Bartz, »Remembering the Hippocratics, 17. 
vešč. Prisega še posebej izpostavlja spoštovanje načela enakosti in nediskriminacije bolnikov, kajti zdravnik pri svojem delu ne sme odstopati od tistega, kar se je naučil od sprejete medicinske doktrine -, njegove storitve morajo zato biti enake kakovosti za bogatega in za sužnja. Tudi v tem delu se je antična praksa razlikovala od zahtev prisege, vendar še danes ta vprašanja ostajajo nerešena, ker marginalnim socialnim skupinam v praksi (in velikokrat tudi zakonodajno) ni zagotovljena enaka dostopnost in kakovost zdravstvenih storitev.

$\mathrm{V}$ tretjem sklopu prisega zavezuje zdravnika k življenju. Jasno se opredeli do evtanazije, pomoči pri samomoru in prekinitve nosečnosti. Zdravnik ne sme napačno svetovati, ne sme dati smrtonosnega zdravila, niti na prošnjo bolnika niti pod drugim pritiskom. Tudi ženski ne sme pomagati pri splavu. Prisega od zdravnika terja, da spoštuje svetost življenja in s svojimi dejanji aktivno ne posega v odločitve o začetku in koncu življenja, kar ima poleg metafizične razsežnosti povsem praktičen pomen za vsakodnevno prakso, kjer je zdravnikovo splošno vodilo ohranjanje življenja in ne izpraševanje o smiselnosti ohranjanja življenj, »ki jih ni vredno živeti,« kajti kršitve načela svetosti življenja lahko hitro ogrozijo neposredne bolnikove koristi in pripeljejo do skrajnih evgeničnih postopkov ter drugih ukrepov, ki so se v nacistični Nemčiji končali z genocidom, $v$ nekaterih drugih razvitih državah pa odražali $v$ grobem kršenju temeljnih človekovih pravic najbolj ranljivih skupin prebivalstva. ${ }^{17}$

Hipokratski zdravnik je dober opazovalec in ve, da se večina ljudi oklepa življenja za ceno velikega trpljenja, kar kaže, da ima življenje posebno vrednost in dražest. Hipokratsko tradicijo in misel nadaljuje tudi Aristotel, ki opozarja, da je življenje takšno dobro, da se ga skoraj vedno obravnava kot implicitni cilj in dobro v vseh presojah ali vsaj kot pogojni cilj znotraj slojevitih ciljev človeškega delovanja. Čeprav prepoznamo prizadevanje za življenje v ozadju človeškega delovanja in vseh drugih človekovih ciljev, se pomen dobrega, ki je življenje, lahko tudi spremeni, ko razmišljamo o prekinitvi življenja, zato se Hipokratova prisega zavzema za življenje v vseh okoliščinah. Tudi Aristotel opozarja, da bi bila postavitev praga, pod katerim bi življenje izgubilo vso vrednost, težavna, zlasti zaradi elementa vrednote, ki se kaže kot objektivno in subjektivno dejstvo. Za hipokratskega zdravnika in kasneje tudi Aristotela, ki verjetno črpa iz te tradicije, nedvomno obstaja določen element vrednosti že v dejstvu, da je človek živ, če le ni prevelikega presežka na strani življenjskih muk. ${ }^{18}$ Tako pravi Aristotel v Politiki: "Za ljudi gotovo obstaja razsežnost lepega tudi $\mathrm{v}$ tem, da zgolj živijo $\mathrm{v}$ politični skupnosti, če tega preveč ne presežejo težave vsakdanjega življenja. Jasno je, da se mnogi ljudje oklepajo življenja, četudi prenašajo veliko trpljenje, kar kaže, da je v življenju samem neko dobro počutje in naravna dražest.«(1278b25-30).

Prepoved sodelovanja zdravnika pri prekinitvi življenja ne izključuje možnosti,

17 Hanauske-Abel, »Not a Slippery Slope or Sudden Subversion, « 1458.

18 Anagnostopoulos, »Euthanasia and the Physician's Role, « 281-86. 
da je v nekaterih okoliščinah potrebno dopustiti, da se življenje izteče ali da se ga prekine. Te odločitve niso nujno del medicinske prakse, čeprav se neomajnost ciljev medicine in zdravniške avtoritete še danes odraža v mišljenju tistih, ki pripisujejo glavno besedo o vprašanjih življenja in smrti zdravnikom, ker imajo znanje o telesnih stanjih in lahko predvidevajo razvoj bolezni. Ob soočanju s smrtjo, ki se dotika nerazumljivosti in predstavljivosti ter se odpira h kazuistiki neskončnega in večnega, se zastavljajo temeljna filozofska vprašanja. Ta vprašanja povezujejo filozofsko antropologijo in etiko. ${ }^{19}$

V četrtem sklopu prisega jasno izpostavi, da je zdravnik dolžan ohranjati svoje življenje in svojo vedo neomadeževano in sveto. $S$ tem zdravnik ni zavezan zgolj zakonom bivajočega temveč zakonom biti, ki niso vezani na čas in prostor. Eden od teh zakonov je tudi svetost življenja. Za udejanjanje teh zakonov zdravnik v skladu s svojo vrlino lahko zastavi le samega sebe.

V petem sklopu se zdravnik zaveže, da ne bo opravljal kirurških posegov, ki jih ni vešč, temveč bo to prepustil drugim strokovnjakom. Takšno razumevanje besedila zahteva od zdravnika določeno varnost in kakovost storitve. Zdravnik mora biti kritičen do svojega znanja in veščine in mora v tem smislu svojemu delovanju postavljati omejitve ali pa poiskati nasvet in pomoč kolegov. Nekateri avtorji ta del navezujejo na določeno filozofsko tradicijo (pitagorejci), ki zagovarja nedotakljivost človeškega telesa in zavrača stik s krvjo. ${ }^{20}$ Razprave o vplivih pitagorejcev na prepoved prekinitve življenja so kompleksne in pogosto večznačne, ker le-ti zavračajo človekovo avtonomijo pri vprašanjih življenja in smrti ter odločitev prepuščajo bogovom. ${ }^{21}$ Ta del prisege ostaja odprt za interpretacijo, saj se ga lahko razume kot prepoved kirurških postopkov, ki so v tistem času pomenili veliko tveganje, lahko bi govoril o odnosu zdravnikov do kirurgije, ki so jo imeli za manj vredno, lahko pa je njegov smisel tak, kot ga razumemo mi, se pravi, da prisega prepoveduje prakticiranje medicine izven meja zdravnikovih sposobnosti, ker bi bilo to lahko za bolnika smrtno nevarno. Vsekakor prisega z zagovarjanjem svetosti življenja odraža temeljna človekova prepričanja o vrednosti življenja in hkrati pričakovanja ljudi o tem, kako naj bi zdravnik ravnal pri teh vprašanjih.

V šestem sklopu prisega izpostavi prvenstvo bolnikove koristi kot vodilo zdravnikovega delovanja in hkrati nedopustnost krivičnih ter drugih dejanj, še posebej ljubezenskih dejanj do bolnikov, ne glede na njihov status. Z vidika sodobnega razumevanja človekovih pravic in nediskriminacije določenih skupin ocenjujemo za pomembno, da prisega posebej izpostavlja spoštovanje načela enakosti, kajti govori o koristi vseh bolnikov in še posebej navaja najbolj ranljive skupine, kot so bili sužnji. V tem delu prisega zagovarja spoštovanje enakosti med ljudmi in izogibanje koruptivnih dejanj, ker se je le na takšen način mogoče izogniti stranpotem zdravništva.

19 Jonas, Le Droit de mourir.

20 Nutton, »Hippocratic Morality and Modern Medicine,« 53.

21 Anagnostopoulos, »Euthanasia and the Physician's Role,« 263-66. 
V sedmem sklopu se zdravnik zaveže $\mathrm{k}$ molčečnosti o vsem, kar mu je znanega o življenju bolnikov in njihovih družin in s tem $\mathrm{k}$ spoštovanju zaupnosti podatkov in zasebnosti posameznika, kar so danes zahteve mednarodnega prava človekovih pravic.

V zaključku, v osmem sklopu, je navedena kazen za kršitev prisege, ki ima "metafizične« in strokovne ter obče človeške razsežnosti, kajti zdravnika zadene nesreča v stroki in življenju. Danes kršitev prisege ni sankcionirana, ker to področje podrobno ureja zdravstvena zakonodaja, ki vedno vključuje tudi sankcije za kršitev določil.

Hipokratova prisega izpostavlja temeljna načela medicinskega delovanja in hkrati izraža splošne človeške moralne vrednote, ki pogojujejo odnos bolnik zdravnik. Prisega še vedno velja za največji dosežek razvoja strogih etičnih konceptov v medicini, ki se ohranjajo do današnjih dni. Glavni namen svečane prisege je izraz in potrditev osrednjih vrednot stroke, ki jih terja kompleksnost medicinske prakse in večplastnost njenih ciljev, ter okrepitev zdravnikove profesionalne integritete. Hipokratova prisega je petindvajset stoletij utemeljevala življenjski in poklicni kredo, načela, nazore in prepričanja medicinske stroke. Še vedno predstavlja jedro deontoloških kodeksov in moralno vodilo, na katerega se sklicujejo zdravniki pri zagovarjanju moralnih odločitev. Njena uporaba kaže na zavezanost trdnim moralnim načelom medicine in njeni tradiciji.

\section{OŽIVITEV ZANIMANJA ZA HIPOKRATOVO PRISEGO}

Nekateri avtorji menijo, da je bila prisega $\mathrm{v}$ teku zgodovine po eni strani najbolj spoštovan dokument, po drugi stran pa pogosto napačno razumljen dokument, ki je zato doživel številne spremembe. Prisega naj bi bila po antiki ponovno uporabljena na medicinski fakulteti šele leta 1508, in sicer na Univerzi Wittenberg v Nemčiji, kot del slovesnosti ob prejemu diplom pa se uporablja šele od leta 1804, ko so jo vpeljali na Medicinski fakulteti v Montpellieru. Hipokratovo prisego je v začetku 20. stoletja zadela nemilost, verjetno zaradi hitrega znanstvenega napredka. V vse bolj racionalističnem vzdušju se je prisega zdela zastarela, nepomembna in nezavezujoča. Leta 1928 je le $19 \%$ medicinskih fakultet v ZDA vključilo prisego v zaključno slovesnost ob podelitvi diplom.

$\mathrm{Z}$ razkritjem vojnih zločinov, ki so bili storjeni $\mathrm{v}$ imenu medicine med 2. svetovno vojno, se je medicinska stroka ponovno oprla na zgodovinske temelje medicinske etike in stroke, kot jih je zapisal Hipokrat. Zaradi številnih dilem, ki jih je prinesel napredek medicine, zlorab in celo kriminalnih dejanj, ki so se zgodila $\mathrm{v}$ imenu napredka medicinske znanosti ter družbenega razvoja (npr. evgenika), in predvsem zato, ker je večina zdravnikov ohranila jasne cilje svojega poslanstva, je zanimanje za prisego, medicinsko etiko in bioetiko ponovno oživelo kot tisti nujni, 
vendar zanemarjeni del medicinske prakse. Medicinska stroka je spodbudila interes za prisego in na njenih idealih izgradila nacionalne kodekse medicinske etike, na ravni mednarodne skupnosti pa smernice, deklaracije in konvencije, na katerih temeljijo nacionalni zakoni za zagotavljanje človekovih pravic $\mathrm{v}$ zvezi $\mathrm{z}$ biomedicino in za izvajanje varnih in kakovostnih zdravstvenih storitev.

Svečana zaprisega je dobila pomembno vlogo na skoraj vseh medicinskih fakultetah, vendar pa je bilo njeno besedilo pogosto spremenjeno in prilagojeno družbenim vrednotam, navadam in prepričanjem. Objavljeni so bili številni članki in knjige, ki obravnavajo pomen Hipokratove prisege. ${ }^{22}$ Stekla je razprava o mestu prisege ob koncu študija medicine in o pomenu priseg in kodeksov za sodobno medicinsko prakso, čeprav je večina medicinskih komentatorjev mnenja, da je kakršnokoli priseganje $\mathrm{v}$ času prevlade utilitaristične etike, kjer je glavno vodilo finančna učinkovitost in korist družbe, v praksi neučinkovito. »Humanistična u usmerjenost medicinske prakse se danes zdi vse bolj ogrožena. Medicinska stroka, ki se tradicionalno čuti odgovorna za blaginjo bolnikov in zdravje skupnosti, ponovno tehta in preverja naravo svojih vrednot. Za moralno usmeritev in vrednotenje svojega položaja v kompleksnih zdravstvenih sistemih se je ponovno obrnila k Hipokratovi prisegi. Priseganje je postalo pomemben del začetka ali zaključka šolanja na mnogih medicinskih šolah. Študije so pokazale, da danes približno polovica medicinskih fakultet v Veliki Britaniji in skoraj vse v ZDA uporabljajo neke vrsto prisego. To je običajno ob izročitvi diplome, redkeje ob začetku študija. Nekatere šole uporabljajo posodobljeno verzijo Hipokratove prisege ali Maimonidovo molitev ali Ženevsko deklaracijo, nekatere pa imajo svojo prisego. Tudi sam obred zaprisege se razlikuje. Nekatere fakultete zahtevajo pisno potrditev, ponekod se prisega glasno prebere ali recitira v zboru. V kolikšni meri je zaprisega prostovoljna, ni zabeleženo. Ni znanih primerov, da bi študenti zavrnili zaprisego, in ne vemo, kakšne bi bile posledice, če bi to storili. ${ }^{23}$

Hipokratova prisega se je preko stoletij spreminjala, da bi odsevala prepričanja določenega časa. Iz mnogih različic prisege so izločili načela, ki ne odsevajo določenih medicinskih praks, in vnesli druge ideale, pomembne za določeno strokovno in socialno okolje. Načelo bolnikove avtonomije je na primer za današnjo medicinsko prakso pomembno, vendar ga Hipokratova prisega eksplicitno ne omenja. Nekateri avtorji zato menijo, da prisega ne ustreza več zahtevam sodobne bioetike, ki poleg načela bolnikove koristi in načela minimalne škode za zdravje izpostavlja načelo avtonomije in pravičnosti. ${ }^{24}$

Podobno velja za druga načela, ki izhajajo iz prava človekovih pravic in predstavljajo danes pomemben del številnih izjav, ki se sprejemajo namesto prevoda

\footnotetext{
22 Millard, »Resurgence of Interest in Medical Oaths," 1749; Markel, »I Swear by Apollo,« 2026-29.

23 Hurwitz in Richardson, »Swearing to Care,« 1672.

24 Nutton, »Hippocratic Morality and Modern Medicine,« 51-55.
} 
Hipokratove prisege. Slednjo v njeni prvotni obliki uporablja le še majhno število medicinskih šol. Tudi Ženevska zdravniška zaobljuba, ki jo je leta 1948 (s kasnejšimi dopolnitvami) sprejelo Svetovno zdravniško združenje (z njo zaprisežejo slovenski zdravniki), stroge zahteve Hipokratove prisege razrahlja in jih postavi v okvir koncepta človekovih pravic: »Človeško življenje bom v največji možni meri spoštoval od spočetja dalje. Tudi grožnje me ne bodo prisilile, da bi svoje zdravniško znanje uporabljal zoper zakone človeštva. ${ }^{25}$ Večina sodobnih različic prisege ne opredeli kazni za kršenje določil, pogosto je izpuščena prepoved opravljanja evtanazije in splava, prav tako redka je tudi prošnja h kakemu božanstvu, še redkejša pa je ohranitev zaobljube spolne vzdržnosti pri stikih s pacienti.

Ali je Hipokratova prisega oziroma njene sodobne naslednice danes še vredna upoštevanja, bo verjetno ostalo vprašanje akademskih razprav. Nekateri avtorji trdijo, da prisega kaže na zavezanost trdnim moralnim parametrom in da njena uporaba v medicinskih šolah lahko okrepi zdravnikovo odločenost, da bo v ekstremnih okoliščinah ukrepal z vso svojo integriteto. ${ }^{26}$

Ne glede na izid nadaljnje uporabe Hipokratove prisege v medicinskih šolah bo zdravnikova zavezanost skrbi za bolne vedno hvalevredna. Zdravnikovo zavzemanje, kolikor mu dopuščajo sredstva, da zdravi tiste, ki v svetu trpijo zaradi telesnih ali duševnih bolečin, potrjuje Hipokratova načela in moč koncepta, ki ga simbolizira prisega. Ta se ohranja skozi zgodovinska obdobja, čeprav $\mathrm{v}$ različnih verzijah, ki vendarle ohranjajo bistvo misli in premisleka Hipokrata Asklepijada s Kosa. ${ }^{27}$

\section{HIPOKRATOVA PRISEGA KOT ZGODOVINSKI TEMELJ REFLEKSIJE O DOBREM IN MEDICINSKE DEONTOLOGIJE}

Hipokratova prisega je sestavni del šestdesetih spisov, ki jih danes poznamo pod imenom Corpus Hippocraticum. Že za svojega življenja je bil Hipokrat tako slaven, da so mu pripisali celoto medicinskih del 5. in 4. stoletja pr. n. št. Zgodovinarji so si edini, da je velik del spisov nastajal vsaj sedemdeset let in da je bil med avtorji tudi Hipokrat. Delo kaže notranja neskladja, hitre spremembe stila in različne, tudi med seboj inkompatibilne poglede na svet. Kljub določeni neskladnosti in neenotnosti misli, ki je razvidna predvsem pri obravnavi razmerij med medicino in filozofijo, verjetno zaradi prispevka avtorjev, ki so pripadali različni medicinski tradiciji, Corpus Hippocraticum kot celota izraža določeno temeljno enotnost misli tako pri prikazu odnosa zdravnika do bolnika, kakor tudi do opazovanja, preučevanja in zdravljenja bolezni. In prav to specifično naravnanost zdravnika in njegovo razumevanje življenja in sveta lahko poimenujemo hipokratska medicina.

25 Dolenc, Medicinska etika in deontologija, 44.

${ }^{26}$ Hurwitz in Richardson, "Swearing to Care, « 1672.

27 Baulieu, »Hippocrate, le 'père' de la médecine, 41. 
Velik del hipokratskih spisov zveni zelo sodobno, $\mathrm{v}$ današnjem medicinskem jeziku bi lahko rekli, da je Hipokrat sledil biopsihosocialni paradigmi obravnave človeka in bolezni. Pod njegovim imenom je medicinska stroka prvič razmišljala o svojem delovanju, o svojih metodologijah in o svoji etiki. Medicinsko prakso je Hipokrat utemeljil na razumu in jo odvrnil od neracionalnih mitoloških prepričanj. $\mathrm{V}$ tem času se prvič $\mathrm{v}$ zahodni zgodovini medicina postavi na znanstvene temelje in obravnava človeka kot celoto $v$ interakciji z njegovim okoljem. Hipokrat je iskal razlage za zdravje in bolezen $v$ samem človeku, v njegovem odnosu do sebe in okolja in ne več $\mathrm{v}$ odnosu do bogov. $\mathrm{V}$ tem smislu se medicinski spisi integrirajo $\mathrm{v}$ tedanje miselne tokove in razmislek o človeku, o njegovem položaju v svetu in njegovi zgodovini. Človek je obravnavan kot odraz svojega okolja, tako fizičnega kakor tudi moralnega, kajti človeško telo sledi ritmu narave in letnih časov ter spremenljivim vplivom zunanjega okolja.

V celoti misli hipokratskih spisov Hipokratovo prisego razumemo predvsem kot moralni razmislek, ki utemeljuje načine ravnanja in razmerja znotraj medicinske prakse, kot razmislek o dobrem in slabem ravnanju zdravnika ter o njegovem odnosu do bolnika, učiteljev, kolegov in do sveta. $S$ te perspektive prisega utemeljuje medicinsko etiko kot širše polje refleksije in lahko pomeni tudi temelj sodobnega koncepta človekovih pravic. Čeprav se prisega običajno šteje za predhodnico medicinskih deontoloških kodeksov, trdimo, da je ne moremo razumeti zgolj kot neko togo pravilo, ki opredeljuje ravnanje zdravnika v odnosu do bolnika in razmerja znotraj medicinske prakse, temveč jo razlagamo v njeni kompleksnosti in večplastnosti.

Prisega je utemeljena na celovitem premisleku o človeku in človeškem dobrem, o človekovem odnosu do sebe, drugih ljudi, narave in sveta, o zdravju in bolezni, človeški krhkosti in ranljivosti ter o zdravnikovem delovanju znotraj ciljev medicine. Pri obravnavi vprašanj zdravja in bolezni, dobrega življenja in smrti je potreben tehten premislek o izbiri postopkov zdravljenja in načinov delovanja, potrebno je zagotoviti pretok znanja in kakovost izobraževanja, kjer je vsestranska odličnost učitelja bistvenega pomena. Znanje, veščine in vrline, potrebne za učinkovito medicinsko delovanje, se izgrajujejo $\mathrm{v}$ procesih stalnega vrednotenja praks, $\mathrm{v}$ kompleksnem odnosu učitelja in zdravnika do bolnikov, kolegov, učencev in družbe, v duhu medsebojne človeške solidarnosti in povezanosti, ki zagotavlja bolniku varnost in kakovost storitve, zdravniku osebni razcvet, priznanje in čast in medicinski vedi napredek v dobrobit človeštva.

Hipokratova prisega na določeni ravni zdravnika brezpogojno zavezuje $\mathrm{k}$ odličnosti in preseganju človeških omejitev, in prav ta vidik brezpogojnosti je danes razrahljan. Sodobna medicina je v veliki meri izgubila »metafizično" razsežnost, ki preveva Hipokratovo prisego. $\mathrm{Z}$ uporabo znanstvenih metodologij je medicina postala utemeljena na naravnih zakonih. Postavila je ločnico med tehničnimi in 
etičnimi vprašanji medicinskega delovanja, ki jo danes znova poskuša zabrisati in preseči. Vprašanja kakovostnega medicinskega delovanja ne moremo več ločevati od razmisleka, kako moralno delovati in $\mathrm{v}$ praksi uresničevati koncept človekovih pravic in zdravja kot izraz človekovega prizadevanja za napredek in kulturni razvoj. Ob relativnosti vrednot potrošniške družbe in prevladi tržnih mehanizmov se je spremenil odnos posameznika do moralnih norm, zato je za doseganje temeljnih moralnih in strokovnih načel medicine potrebno iskati nove mehanizme. Večina razvitih držav danes ta vprašanja rešuje zakonodajno, s tem pa medicinska stroka izgublja svojo vodilno vlogo pri urejanju odnosov v medicini in posledično tudi v družbi.

Moralna načela, na katerih temelji medicinska etika, ne izhajajo iz neke predhodne etične dogmatične teorije ali neke specifične etike medicine, temveč opredeljujejo skupne moralne in strokovne temelje, ki zagotavljajo ohranitev človeškega dostojanstva $\mathrm{v}$ bolezni in trpljenju in učinkovito delovanje zdravnika $\mathrm{v}$ dobro bolnika. Zato so se deontološki temelji medicinske etike navkljub temeljnim spremembam v medicini, ki so bile posledica znanstvenega in tehnološkega napredka ter sociokulturnega razvoja, do danes ohranili in se v bistvenih zahtevah le malo spremenili od zahtev hipokratske medicine. Hipokratova prisega jasno, enostavno in na splošno veljaven način izrazi človeške ideale dobrega življenja, medsebojne povezanosti in strokovnega uspeha, zato je nadčasna in ostaja temelj medicinske etike ter vir refleksije v medicini. V kolikšni meri prisega zavezuje posameznega zdravnika $\mathrm{k}$ odličnosti njegovega delovanja, je odvisno od razumevanja tehničnih, etičnih in človeških razsežnosti medicine ter drugih norm, ki se v času spreminjajo. V svoji elementarni obliki je Hipokratova prisega imela, in še vedno ima, pomemben vpliv na zahodno medicino. $V$ dvomu se zdravniki vedno znova vračajo $k$ zgodovinskim temeljem medicinske etike kot viru refleksije za sodobni čas, ko se postavljajo pod vprašaj temeljne vrednote človekovega bivanja.

Hipokratove prisege ne vidimo kot skupka pravil in definicij, temveč predvsem kot celovit premislek o življenju in strokovnem delovanju, ki izpostavlja določene splošno veljavne moralne in tehnične norme medicine. Prisega potrjuje temeljna načela dobre medicinske prakse ali celovite kakovosti medicinske storitve in ščiti bolnika, ki je zaradi bolezni bolj ranljiv za morebitne zlorabe s strani zdravnika in drugih oseb, hkrati pa nima ustreznih medicinskih znanj (na ta dejstva je opozarjal tudi Aristotel). Prisega ne razrešuje vprašanja hierarhije vrednot, ki so vedno odraz različnih razsežnosti in ravni življenja, polarnosti in konfliktnosti raznih ravni človeka, kakor tudi kompleksnosti njegovega bivanja. Znotraj kompleksnih odnosov medicine norme in vrednote Hipokratove prisege razumemo in razlagamo v nekem dinamičnem ravnotežju, ki se spreminja glede na čas in okoliščine določene situacije. 


\section{ZAKLJUČEK}

V prispevku smo Hipokratovo prisego umestili v optiko hipokratske medicine, ki je utemeljila znanstvenost medicine, čeprav ostaja religiozna. Hipokratski zdravnik je filozof, učitelj in pošten človek, katerega dejanja vodi prizadevanje za dobrobit bolnikov in ne materialna korist. ${ }^{28}$ Iz izhodišč hipokratske medicine, ki preučuje in upošteva človekovo naravno, socialno in kulturno okolje, odkriva naravne zakone, zdravilne postopke (vis medicatrix naturae) ter vzročne povezave, smo prisego tudi razlagali.

Hipokratska medicina povezuje tehnično in moralno razsežnost dejanja pri odločanju o metodah zdravljenja se zaveda negotovih izidov, zato se izogiba skrajnostim in zagovarja kritično refleksijo prakse, poroča o napakah in uspehih ter zahteva upoštevanje moralnih standardov, dobro komunikacijo in sodelovanje bolnika. Iz tega zornega kota prisego razumemo kot moderno, zato smo pri razlagi uporabili sodoben medicinski jezik in govorili o oceni tveganj, zagotavljanju varnosti in kakovosti storitev ter upoštevanju pacientovih pravic.

Kot so pokazali številni avtorji, Hipokratova prisega omogoča različne pristope, razumevanje in interpretacijo znotraj iste civilizacije. ${ }^{29}$ Veliko avtorjev meni, da Hipokratova prisega ne ustreza več realnosti moderne družbe in da se njena bistvena tri načela - spoštovanje svetosti življenja, varstvo zasebnosti in delovanje $\mathrm{v}$ korist posameznega bolnika - danes v praksi vse pogosteje kršijo, spreminjajo in na novo interpretirajo. ${ }^{30}$ Drugi avtorji takšnim stališčem nasprotujejo in menijo, da se $\mathrm{v}$ sodobni medicini vprašanje tveganja in škode za zdravje zaostruje, zato je potrebno oživiti antične ideale, izražene v Hipokratovi prisegi. ${ }^{31} \mathrm{Ti}$ avtorji menijo, da zdravnik deluje $\mathrm{v}$ duhu Hipokratove prisege, če se $\mathrm{v}$ določenih okoliščinah, potem ko pretehta vse odločilne faktorje - voljo pacienta in svojcev, prognozo bolezni, celovito zdravstveno stanje -, odloči, da ne bo aktivno ukrepal in da na primer pacienta ne bo oživljal ali ohranjal pri življenju z modernimi tehnologijami. Načelo prizadevanja za bolnikovo dobrobit dobi širšo razsežnost v okviru razumevanja človeškega življenja in dostojanstva.

Prisega opredeljuje dolžnosti zdravnika, zato je temelj medicinske deontologije, določa pa tudi načela, ki so postala del mednarodnega prava človekovih pravic. Prisega prvenstveno zahteva strokovnost oziroma profesionalnost zdravnika in učinkovito delovanje $\mathrm{v}$ dobro posameznika ter s tem spoštovanje njegovih temeljnih človekovih pravic. Prisega izraža zdravnikov ethos - način njegovega bivanja in delovanja -, to drugo človekovo naravo, ki jo mora zdravnik privzeti, da je pri delu lahko uspešen; zato jo razumemo kot nerazdružljivo vez med medicinsko etiko in medicinsko

\footnotetext{
28 Nutton, »Hippocratic Morality and Modern Medicine, 48.

29 Nutton, »Hippocratic Morality and Modern Medicine,« 49-55.

30 Loeffler, »Why Hippocratic Ideals are Dead,« 1463.

31 Roddy, »On Hippocrates, 496.
} 
vedo $\mathrm{v} v$ seh njenih razsežnostih. V Hipokratovi prisegi smo iskali tiste zgodovinske temelje medicinske etike in prakse (sicer nepopolne), ki v Corpus Hippocraticum povezujejo medicinsko prakso, teorijo, filozofijo, retoriko, pravo in druge vede o človeku in njegovem okolju in s tem vzpostavljajo medicinsko etiko in prakso kot nerazdružljivo celoto medicinskega delovanja in izobraževanja zdravnikov.

Hipokratovo prisego, ki znotraj ciljev medicine zdravniku predpisuje zdravniško delovanje, vpeto med tehnično možno in moralno zapovedano, smo postavili za izhodišče premisleka o univerzalnih normah medicinskega delovanja in prava človekovih pravic. Prisega že več kot dve tisočletji zavezuje zdravnika $\mathrm{k}$ uporabi strokovnih znanj v korist bolnika in zagovarja življenje kot posebno dobro ter postavlja obče veljavne norme, ki so se ohranile do danes.

Hipokratski spisi in Hipokratova prisega pri preučevanju odpirajo različne razsežnosti razumevanja človekovega zdravja, bolezni in življenja v odnosu do narave in kulture, kar hkrati odpira različnim vedam vedno nove možnosti za raziskovanje, vrednotenje in prispevek $\mathrm{k}$ boljšemu razumevanju celote hipokratske misli, ki odzvanja še danes in jo lahko odkrivamo v sodobnih celostnih in individualiziranih pristopih k zdravju človeka, zdravstveni ekologiji, okoljski medicini, medicinskem pravu in drugih vedah o človeku. Hipokratova prisega ne opredeljuje le nalog zdravnika, temveč tudi obveze vsakega posameznika, da zdravo živi v skladu s

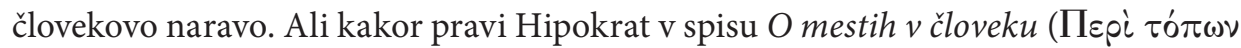

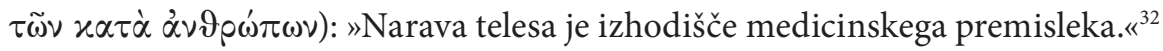

Hipokratska morala je bolj raznolika in bolj kompleksna, kot bi to želela priznati medicinska stroka in sodobna bioetika. Oblikovana je bila za drugačen čas in na drugačni stopnji razvoja medicine, vendar človekovo trpljenje in pričakovanje bolnika zahteva specifičen odgovor medicine, ki ohranja svoje etične temelje. Hipokratski zdravnik je predvsem praktik, a tudi mislec in teoretik, natančen opazovalec človeka in njegovega okolja ter pozoren poslušalec in raziskovalec. In prav v tem je njegova nedvomna originalnost. Hipokratski spisi ohranjajo širino in globino premisleka o kompleksnosti človeškega bivanja $\mathrm{v}$ zdravju in bolezni in $\mathrm{s}$ tem svojo vrednost za današnji čas.

\section{BIBLIOGRAFIJA}

Anagnostopoulos, Georgios. "Euthanasia and the Physician's Role: Reflections on Some Views in the Ancient Greek Tradition." V: Bioethics: Ancient Themes in Contemporary Issues, ur. Mark Kuczewski in Ronald Polansky, 251-90. Cambridge, MA: MIT Press, 2000.

Bartz, Robert. »Remembering the Hippocratics: Knowledge, Practice, and Ethos of Ancient Greek Physician-Healers. «V:Bioethics: Ancient Themes in Contemporary

32 Hp., Loc. Hom. 2. 
Issues, ur. Mark Kuczewski in Ronald Polansky, 3-29. Cambridge, MA: MIT Press, 2000.

Baulieu, Étienne-Émile. »Hippocrate, le 'père' de la médecine.« V: Pour l'amour du grec, ur. Jacqueline de Romilly in Jean-Pierre Vernant, 41. Paris: Bayard Editions, 2000.

Derganc, Franc, prev. »Hipokratova prisega.«Zdravniški vestnik 1 (1929): 29.

Dolenc, Anton. Medicinska etika in deontologija: dokumentiskomentarjem. Ljubljana: Tangram, 1993.

Hanauske-Abel, Hartmut M. »Not a Slippery Slope or Sudden Subversion: German Medicine and National Socialism in 1933.« BMJ 313 (1996): 1453-63.

Heiberg, Johan Ludvig, izd. Corpus medicorum Graecorum 1.1. Berlin in Leipzig: B. G. Teubner, 1927.

Hriberšek, Matej, prev. »Hipokratova prisega.«Lepotni bazar 1 (1999): 9.

Hurwitz, Brian in Ruth Richardson. »Swearing to Care: The Resurgence in Medical Oaths.« BMJ 315 (1997): 1671-73.

Jonas, Hans. Le Droit de mourir. Paris: Eds. Payot \& Rivages, 1996.

Jouanna, Jacques. Hippocrate. Paris: Arthème Fayard, 1992.

»Kazenski zakonik Republike Slovenije.« V: Uradni list RS št. 63/1994. 13.10. 1994.

Lami, Alessandro, izd. Ippocrate: Testi di medicina greca. 8. izd. Milano: Biblioteca Universale Rizzoli, 1996.

Loeffler, Imre. »Why the Hippocratic Ideals Are Dead.» BMJ 324 (2002): 1463.

Markel, Howard. »I Swear by Apollo - On Taking the Hippocratic Oath.» New England Journal of Medicine 350 (2004): 2026-29.

Millard, Peter H. »Resurgence of Interest in Medical Oaths and Codes of Conduct.« BMJ 316 (1998): 1749.

Nutton, Vivian. "Hippocratic Morality and Modern Medicine.« V: Entretiens sur l'antiquité classique 43: Médecine et morale dans l'antiquité, ur. François Paschoud, Bernard Grange in Charlotte Buchwalder, 31-56. Genève: Fondation Hardt, 1997.

Kocijančič, Gorazd, prev. Platon: zbrana dela. Prevod in spremna beseda Gorazd Kocijančič. Celje: Mohorjeva družba, 2004.

Roddy, Edward. »On Hippocrates: Hippocratic Ideals Are Alive and Well in 21st Century.« BMJ 325 (2002): 496.

Sovrè, Anton, prev. »Hipokratova prisega." V: Medicinska etika in deontologija, ur. Anton Dolenc, 21. Ljubljana: Tangram, 1993. 


\section{THE HIPPOCRATIC OATH AND ITS RELEVANCE FOR MEDICAL DEONTOLOGY}

\section{Summary}

The text of the Hippocratic Oath is translated and interpreted in the light of the Hippocratic Corpus writings and the modern concepts of consumer protection, safety and quality of medical services, where one of the possible definitions of quality could be related to customer satisfaction and to the respect for human rights, among them the right to human dignity, to life, integrity, to the protection of personal data and respect for private life. In this broad and complex field of medicine and public health, where moral and human rights issues are interlinked with the technical questions of modern medical science, we search for the ancient foundations of medical ethics and science promoting biopsychosocial approaches to health and an assessment of human functioning in the framework of the social and natural environment. The Oath clearly expresses the commitment of the Hippocratic physician to the highest medical and ethical standards. Moral and technical norms of medicine as stated in the eight parts of the Hippocratic Oath are interpreted from the perspective of the patient's expectations to preserve his dignity in the therapeutic relation with the physician and to receive the best possible treatment. The Hippocratic physician is well aware that he must gain the trust of the patient and his family in order to be successful in his practice and achieve the best treatment results. To attain these goals, he needs to secure the patient's cooperation as an essential element of the treatment process. To gain this fundamental trust, the physician must be an honourable and trustworthy person who abstains from all intentional wrong-doing and harm, corruption, sexual abuse, or any other act that might endanger the life of the patient. His primary ethical guidance must be the best interests of the patient and consideration of the highest medical technical standards. For these purposes he must constantly examine and critically analyse his practice and theory. The Hippocratic physician builds his medical theory on a close observation of the human body and natural phenomena in order to establish aetiological links between the causes of disease and the outcome of the treatment. In this respect we consider Hippocratic medicine the foundation of scientific medicine, as well as of medical and philosophical ethics, forensics, ecology, and other natural and social sciences and the humanities. Interdisciplinary and horizontal approaches to health and disease require medical knowledge, but equally important is the sociological, philosophical and other input. An attempt is therefore made to read the Oath as a very elementary expression of a complex and multilayered reflection on the duties of the medical profession, on the issues of health and disease, on man and his environment, on the complexity of life and nature. The Hippocratic Oath emphasises the role of the teacher and the need to 
gain the necessary knowledge and expertise in an educational process that establishes a linkage between technical and moral norms, binding the Hippocratic physician in the totality of his personal and professional life. There are various interpretations of the relevance of the Oath for medical ethics today, at a time of highly technical medicine, consumerism, market economy and prevalence of utilitarian ethics. When in doubt, however, the modern physician still turns to the Hippocratic Oath as a source of reflection and guidance. In the last decades there has been a revival of interest in medical oaths and codes of conduct. Modified versions of the Hippocratic Oath are used in medical schools to reconfirm the core values of the medical profession. Although Hippocratic morality reflects different times, the core ethical statements in the Hippocratic Oath have remained relevant for almost 2500 years. This long tradition of medical ethics reconfirms the need for preserving the idealistic foundations of medical practice and its humanistic orientation, which guarantees that the criminal actions of the Nazi medicine will not happen again and that every human being will be treated with dignity in situations of extreme vulnerability. 